Image and Man - Correlations, eds. Marcin Godawa, Bojan Žalec, Krakow 2020, pp. 103-117. DOI: http://dx.doi.org/10.15633/9788374386807.10

Bojan Žalec

University of Ljubljana, Slovenia

\title{
Islamophobia as a False Image of Islam and a Negative Factor of Intercultural Dialogue
}

\section{CHARACTERISTICS OF ISLAMOPHOBIA}

Green defined Islamophobia (hereafter IPH) as follows:

"Islamophobia: hatred, hostility, and fear of Islam and Muslims, and the discriminatory practices that result." (Green 2015, 9)

He alleged the following characteristics or elements of it:

a) Islam as a Monolith

This presupposition is very favourable for IPH since it makes possible to generalize acts of some Muslims to all Muslims. So for example in Saudi Arabia women are prohibited to drive cars. From the concerned presupposition one can conclude that this applies to the whole Muslim world; but this is not so. Muslim countries with this prohibition are in minority. Even more drastic example: Al Qaeda commits a crime, and some think that this crime is approved by all Muslims, although this is not true at all. The third example is Barack Obama. Some people have tried very hard to proclaim him for a Muslim: because of his Muslim father, his years spent in Indonesia, and because of his middle name Hussein. The motif of Obama's adversaries in Islamophobic atmosphere - where many accept the concerned presupposition - is clear. At the other hand, the acts and convictions of Andreas Breivik, Norvegian murderer, nobody or very few generalised to all Christians (Green 2015, 12-13). 
b) Islam as Separate and Other

The second characteristic of IPH is the claim that in Islam there aren't values which can be found as the most important in other religions, especially in Judaism and Christianity, or in the Western culture. So for example it is claimed that in Islam there are no values as religious diversity or religious freedom. This conviction (belief) is obviously present in the statement of Ulrich Schlüer, a member of the Swiss People's Party, who was the most important person in the Swiss very successful campaign for the prohibition of building new minarets in the state. TV reporter asked him whether it is right that minarets are prohibited but bell towers not. Schlüer answered that these two cannot be compared since Christianity is a religion which consists of values as tolerance, respect of different thinking etc., whereas we cannot say the same for Islam. With other words Schlüer expressed the opinion that Christianity includes secular values of freedom and tolerance which are alien to Islam. Therefore we cannot allow placing symbols of such culture which is alien to the Swiss one (Green 2015, 13-14).

c) Islam as Inferior

The third, similar claim is that Islam is not only different, but also inferior compared to the West. Islam is barbaric, unreasonable and sexist, contrary to the reasonable, enlightened, and the equality between genders cultivating West. Ayaan Hirsi Ali often speaks about Islam in such way. She poses the Enlightenment principles like freedom of researching and freedom of an individual in contrast with Islam. According to her, Islam is not compatible with the principles of liberty which are the core of the Enlightenment heritage. ${ }^{1}$ The obsession of Islam with the subordinating of women is for

1 See Hirsi Ali 2010, 214. The IPH elements are present also in the Oriana Fallaci's bestseller (2004), including the theses that the Islamic culture is inferior to the Western one, that Qur'an is full of absurdities despite the fact that it is, according to Fallaci, just (a bad) copy of the Torah, Bible and Hellenistic thinkers (Fallaci 2004, 93) etc. For the (pro- or neo-Enlightenment) presentation of the debate on the significance of the Enlightenment (from the aspect of tolerance, freedom of speech...) in the context of our contemporary (European) problems with radical Islamism (for instance the murder of Theo van Gogh in Amsterdam) see Cliteur, Gordon 2009. The authors stress the importance of the work of the British historian Jonathan Israel (see Israel 2001, 2006). They conclude their essay with the following sentences: "Contemporary followers of Spinoza, Bayle and Diderot claim to know what we should do: advocating enlightened morality with a firm rejection of a worldview that undermines liberal democracy. Murder in Amsterdam represents not only a rejection of that proposed course, but demonstrates the guilt complex that lies at the heart of this rejection: 
her one of the things which make Islam reprehensible. According to her Islam has nothing to offer to the West since it is intellectually, culturally and ethically inferior to it (Green 2015, 14-15).

d) Islam as an Enemy

According to this view, Islam is considered as an enemy, aggressive and violent. Islam is a religion of conquest, and therefore the clash of civilizations between Islam and the West is unavoidable. Green points out that such stance - which presents Islam as necessarily connected with violence and terrorism - shapes not only the foreign, but also the internal policy of the Western states, which limits the life of Muslims in the West, or exposes them as especially suspicious regarding terroristic actions. Such an example is the profiling of Muslim passengers at the American airports (Green 2015, 15). ${ }^{2}$

e) Islam as Manipulative

An example of such standpoint is the opinion that Muslims who live in the West are not sincere regarding respecting of religious freedom, but they are rather only using it for their benefit, waiting for the moment to be strong enough to implement also in the West the shariah law which does not recognise religious freedom. Green mentions a real wave of inferences in the legislation in the USA which started in 2010 and was driven with the mentioned conviction (that Muslims in the USA only misuse the $1^{\text {st }}$ amendment of the USA constitution and that this abuse should be prevented) (Green 2015, 15-16).

f) The Justification of Race Discrimination against Muslims

Runnymede Report ${ }^{3}$ reports that racism and IPH are often mixed together in the British context; consequently racist feelings and anti-Muslim

the Holocaust and a failed colonial history receive great attention, precluding the reluctance to affirm an Enlightenment tradition that has seen the terrible abuses occur on its watch and often in its name. Jonathan Israel reminds us however, that abuse of an argument is not proof positive of its failure. We should not throw the baby out with the bath water, and we should not suffer inferior [underlined by B. Ž.] political and cultural paradigms because we have not lived up to something better." (Cliteur, Gordon 2009, 330)

2 The book of Sousan Safaverdi, 27 Hours in J.F. Kennedy Airport is very relevant in this regard. In it she described the maltreatment of her which was caused (only) by the fact that she is a Muslim.

3 The name often used to refer to the report from 1997 titled Islamophobia: A Challenge for Us All made by the Commission on British Muslims and Islamophobia created by the Runnymede Trust. The commission was established one year earlier, and the trust itself in 1968 with the purpose to counsel the British government on race relations (Cf. Green 2015, 9-11). 
emotions are often connected. In other European contexts there could be a connection of anti-Arabic and anti-Muslim sentiments. Shortly, if it is for Muslims, racist attitude and praxis come to light. An example is (again) the profiling of Muslims at American airports which is justified not only with religious identity of Muslims, but also with their race belonging and with the supposed "fact" that a Muslim can be very quickly recognized on the basis of his/her outlook, which, supposedly, includes also the colour of his/her skin etc. (Green 2015, 16-17).

g) Muslim Criticism of the West Is Not Valid

According to this view, the Western criticism of Islam is a one-way street. Western politics, religious leaders and journalists can criticize Muslims and Islam as they like, but they do not really take into account and appreciate the Muslim criticism of the West, of its factual - not only declared - values and practices. For example, in many Western countries there are going on discussions regarding different aspects of the freedom of speech, about its boundaries etc. Many Western countries prohibit by law certain discourses and statements. In some European countries a denial of Holocaust is a criminal act. In principle there is nothing wrong with such prohibitions since liberal democracy is compatible with the regulation of the freedom of speech. Besides, as Slavoj Žižek (2015) stressed, there is no culture without its taboos. Just try to be "indecent" toward holocaust on the West. You will be immediately excommunicated. But when Muslims protest against inappropriate attitude towards their values they are almost not taken into account at all. A good example supporting this thesis is the Danish affair with the caricatures of the prophet Mohammad. A big part of the Western public has not considered Muslims' affect but rather condemned them of being incapable to understand and accept the Western dedication to the freedom of speech (Green 2015, 17-18).

h) Anti-Muslim Discourse Is Natural

Runnymede Report reports that anti-Muslim discourse permeates the thinking of people in the West so intensely that even many of public persons who are otherwise sensitive to intolerance and prejudices against others, do not react in the case of Muslims and these things seems normal to them. Green alleges an example of a respectable journalist Juan Williams who publicly stated that when he sees a Muslim in the airplane he becomes nervous. His media house (NPR) fired him but afterwards another house employed him (Fox News). The subject of the public 
discussion was the justification of his dismissal, and not his statement. If Afro-Americans or Jews were in question this could hardly happen. But because he articulated feelings of many in the USA, the attitude towards his statement and his dismissal was such (Green 2015, 18).

\section{ORIGINS OF IPH}

\subsection{ORIENTALISM (THE CLASH OF CIVILIZATIONS THESIS)}

Maybe the most prominent partisan of the thesis about the clash of civilizations is Samuel Huntington (see Huntington 1993 and 1996). ${ }^{4}$ But the real author of this thesis is an American Orientalist Bernard Lewis. He was a professor at Princeton University. He had cultivated the discourse of the "clash of civilizations" already decades before he published his influential article from 1990 titled "The Roots of Muslim Rage," but in this article his idea really took off. Lewis noted that classical Islamic theology has quickly separated the World into two parts: into the house of Islam where Islamic laws prevail, and into the house of war, sometimes called also the house of non-religion where Islamic laws are not recognized. According to Lewis, all Muslims should aim that - through the holly war - parts of the second house are included in the first house. Lewis claimed that this aspect of the Muslim thought generates a situation for arising of tension with Christianity, and this tension has been lasting from the $7^{\text {th }}$ century on

4 For useful observations, despite some drawbacks, on Huntington's concept(ion) of civilizations see Armstrong 2009, 15-18. Armstrong stresses the importance of identity crisis (Armstrong 2009, 15) and Huntington's conclusion that the real clash is not the clash between civilizations but rather between civilization and barbarism (Armstrong 2009, 18). To the first point Armstrong wrote: "There is a grand narrative that goes like this: During the period of the Cold War the geopolitical map was divided ideologically into the Free World and the Communist Bloc. Most countries had to stand in one line or the other making, at times, strange companions. Afghanistan was aligned with the Free World, not because of any deep affinity, but because it was engaged in fighting Soviet forces. With the end of the Cold War, in the final years of the 1980s, this way of seeing the world became obsolete; a crisis of identity ensued. Instead of Capitalism versus Communism, the world divided up according to a very different sort of loyalty: a loyalty premised on civilizations. In the book that made the running on this issue, The Clash of Civilizations, Samuel P. Huntington put it like this: 'In coping with the identity crisis, what counts for people are blood and belief, faith and family."' (Armstrong 2009, 15) 
till today. Islam had the upper hand in this rivalry till the defeat in the battle of Vienna in 1683. From then on Christian and post-Christian civilization have almost always defeated its Muslim opponents. This change of fortune is the basis for the enmity of Muslims towards the West, their old rival (and this enmity rises more and more) (Green 2015, 90-91).

After the review of the history of the very stormy relation of Islam towards the West, Lewis turns to the question at hand: Why are Muslims today so hosting towards the West? He makes a list of possible reasons for anti-Americanism and anti-Westernism: the American support to Israel; the American support to unpopular regimes in the Middle East; Western history of sexism, racism and imperialism etc. But Lewis over and over again rejects these candidates as good reasons for the Muslim wrath and rage, respectively saying that such a rage cannot be explained with anything that has been done by the Western people and that the reason must be in Islam itself or in it as such. Lewis concludes the paper with a passage titled "A Clash of Civilizations." In it he finally explains the real "reason" for Muslims' enmity towards the West: jealousy and humiliation because of the dominance of the Western civilization. Especially two Western characteristics have been the targets of the Muslim rage: secularism and modernism (Green 2015, 91).

But, as Green points out, this has not been always so (Green 2015, 91). Many Muslims at the beginning admired these two "progresses" in the Western civilization and they even tried to install or include them, respectively in their societies. But Muslims have never been successful in doing this. Instead there have been poverty, tyranny, and war defeats. This has opened the door to the Islamic fundamentalists who have persuaded many in the Muslim world that the "original" Islam is necessary for an effective answer to the threat of the West. By the opinion of fundamentalists, an entrenchment into the anti-modern, anti-secular Islam of the old nature is the best means for the Muslim world to deal successfully with its big inferiority complex (Green 2015, 92).

According to Lewis there is a clash of civilizations between Islam and the West. This clash is unavoidable not because the Western people have done anything wrong, but because the unreasonable Muslim world is captured in wrath, jealousy and enmity. The West can do very little to prevent the conflict, apart from helping that the more moderate voices prevail inside Islam. Here we can find many classical Oriental themes. Lewis characterizes 
Islam and Muslims, respectively as monolithic, left behind, irrational (unreasonable), and emotional (full of wrath). Contrary to them the West is dynamic, modern, progressive and reasonable, and it controls its emotions. With this Lewis has offered a clear Orientalist frame which helps modern Americans and Western people to explain the fact that "they" hate us, and to legitimize the feeling of the Western superiority and exceptionality which can consequently help with the self-confidence and reassurance of the West in its efforts to preserve its dominance - political, economic and military over the Muslim world (Green 2015, 92-93).

\subsubsection{SAID'S CRITICISM OF LEWIS AND HUNTINGTON}

Among the most sharp and prominent critics of Lewis' account is Edward W. Said (cf. Said 2003; Green 2015, 96ff). As first, Said criticises Lewis' method (Said 2003, 71). He reproaches Lewis with unjustified generalizations, frivolous misrepresentation of history, and degradation of the (non-Western) civilizations to categories like irrationalism, rage etc.

The basic false ideas that Huntington borrowed from Lewis are the conception of civilizations as homogenous and monolithic, and the conviction that the "dualism" between "they" and "us" is unbridgeable. The main objections of Said - which applies both to Lewis and Huntington - are the following: a) Essentializing which serves for justification of the superiority of the West over Islam; b) They do not give a neutral description, but they are advocates of the Western interests; $c$ ) The World is not simple as Lewis and Huntington wish to be; d) They both overlook that civilization identity is not fixed but fluid; e) Such paradigm justifies and reinforces conflicts and separation with the aim to preserve the dominance of the West. On the other hand - according to Said - we need just the opposite: not a conflict, but a community, not a clash, but people coming together. We must overcome cultural differences to be able to face problems which threaten all humanity together (Green 2015, 97-98).

Orientalism and IPH are not the same, although Orientalism has contributed some elements which are essential parts of IPH or which are sources for IPH. Among them we can mention the view which considers Islam as being separated from and inferior to the West, and as race category (what excuses racism). IPH is connected with political power, just as Orientalism is connected with the colonial power in the $19^{\text {th }}$ century. But - as already 
mentioned - Orientalism is not the same as IPH. Some Orientalists deeply admired the culture of Muslim nations or people. Orientalism is not limited to academy, although its primary and most important place is academy, whereas IPH primarily is not a matter of scholars, scientific researches etc. (Green 2015, 98-99).

\subsection{SOME PROMINENT EVENTS FROM THE RECENT PAST}

As first we should mention 9/11 and the war against terror which followed. To justify the war, the American elites have constructed and spread an Islamophobic story about Islam as the most terrible treat for the Western society (its values, freedom, and way of life) which included three Islamophobic stereotypes about Islam: Islam as violent, antidemocratic, and hostile towards women (misogynist). (Green 2015, 103) On this basis the goals (objectives) of the war were defined: struggling against terrorism, introducing of democracy, and the liberation of women. Green shows $(2015,103 \mathrm{ff})$ how American politicians have constructed the Islamic enemy to justify the war and to distract attention from the imperial interests in the Middle East. Results in all three points have been catastrophic.

The most important events on the European ground in the last decades which have given birth to the fear from the Muslim "enemy within," and which have strained the tension between the Muslim minorities and the Non-Muslim majority, are Rushdie Affair, terrorist attacks in Madrid (M-11) and London ( $7 / 7$ ), the murdering of Theo van Gogh in Amsterdam, Danish Cartoon Affair, Charlie Hebdo shooting (January 7, 2015), and especially attacks in Paris on November 13, 2015.

\subsection{INDIVIDUALS AND ORGANIZATIONS WHICH MAKE THEIR} LIVING AND PROFIT BY PRODUCING AND PROMOTING IPH

The terms which are used for them are Islamophobia industry or professional Islamophobia.

Green (2015) showed how such an atmosphere on the both sides of the Atlantic Ocean has worked as fertile soil for some most severe opponents of Islam i.e. those who have been engaged in IPH industry which has humiliated and demonized Muslims for its (own) (professional) gains. He wrote: 
In this chapter, I analyse the arguments, motivations, and influence of prominent individuals and organizations that deliberately drown out the diversity of Muslim voices and consciously manufacture and exploit the fear of Islam in a manner unprecedented in mainstream political and media circles. I refer to this enterprise as 'professional Islamophobia.' Professional Islamophobia is constituted by a cadre of conservative politicians, right-wing activists and bloggers, and even disgruntled Muslims or ex-Muslims who make a career of demonizing Muslims and Arabs. Nathan Lean refers to this cadre as the 'Islamophobia Industry,' whereas the Center for American Progress labels it the 'Islamophobia network.'5 Whatever we call it, what matters is that those who participate in and profit from professional Islamophobia have powerful political, media, and publishing platforms from which to generate and exacerbate Western anxieties toward the Muslim 'Other.' (Green 2015, 205-6)

Negative representations of Muslims and Islam in main news in public media, in TV programs and Hollywood movies are an integral part of IPH industry.

\subsection{GEO-STRATEGIC FACTORS AND FUTURE PERSPECTIVES}

We should point also to the importance of the geo-strategic factors. Ingrid Mattson especially stresses the importance of two factors: 1 . Development and improvement of the more renewable sources of energy; 2. Peaceful solution of the Israel-Palestine conflict (Green 2015, 330). Eboo Patel finds out that - alas - at the areas with the Muslim majority the situation doesn't improve. There are numerous conflicts in these regions. He predicts that in many of them in the next 30 years there will be some form of a civic war (Green 2015, 331). This will have a negative impact upon the perception of Islam on the West. Yet there is a certain hope that the improvement of the relations between Muslims and non-Muslim on the West will mitigate this effect. Some historical parallels offer us the encouraging examples, for instance the improvement of the condition of the Catholic minority in the USA, the decrease of antisemitism and the change of opinion regarding the inter-racial marriages (in the USA). In 1950 only $4 \%$ of Americans approved such a practice. Barack Obama was a president of the USA. Alleged cases all ended in a happy way in the sense of the erosion of the prejudices, so they give us hope that this will also happen in the case of IPH (Green 2015, 334). Because Muslims continue with their taking roots and investment

5 See Lean 2012 and Wajahat et al. 2011. 
in their communities and civil institutions, it is probable that the positive relations between the Muslim minorities and the non-Muslim majority will grow. This will happen in the various parts of the World in different ways and grade, differently in Europe than in the USA. But of course the situation is very complex and the predictions are quite risky. Here we can mention the so called Ramadan's paradox. In Europe Muslims have slowly settled down and they started with the engagement in the neighbourly relations. This already brings and will bring also in the future a greater tension in relations between Muslims and non-Muslims. This generates a paradox to which Tariq Ramadan points out: because Muslims are coming out from their social and geographical ghettos, the impression appears that Muslims in Europe don't integrate. The greater activity and presence of Muslims in public will cause that the fear and anxiety of non-Muslims will increase and come out, respectively. But on the other hand, non-Muslims will become more accustomed to Muslims, the interpersonal contacts will be more common and frequent and because of this the condition can also improve. For these reasons Ramadan estimates that in Europe IPH will in two generations substantially decrease (Green 2015, 334).

\section{SO WHAT CAN (AND SHOULD) WE DO?}

As we can see IPH is strongly supported by powerful forces. So it is not easy to combat it. Still there are several things we can do. Among them, we can mention public pointing to the examples of IPH, disclosing and discrediting of the individuals and institutions which pursue their political and financial gain from spreading of false information about Islam and Muslims, cultivation of interpersonal and interreligious relationships between Muslims and non-Muslims - which include interreligious dialogue and cooperative actions and engagements of Muslims and non-Muslims for the common goals and common good of the society -, and as last but no least the education of public about Islam, especially about its variety and its common denominators with the West and other religious traditions.

It is very important to ask the right questions. One of them is: Why so many non-Muslims have so strong sentiments about Islam although they know so little about it? This opens the question about the origins of the anti-Muslim sentiments in the West. The important topic relevant 
for this question is the role of the Islamophobia industry. Further factor is the ignorance and poor knowledge of the Western people about Islam. It is very important that we are well educated also from the aspect of knowledge about the media (the way they work, act upon us etc.), and psychology (functioning of human mind etc.). People should know that the media are not some objective and neutral source of information. They should consider them in a dialogical way, as a possible source of information which however is incomplete. We should especially care that as much as possible high number of people is aware of some facts that are especially important for better understanding of Islam by non-Muslims. Here we can mention the knowledge about the common elements of Islam and other religions, that Islam is not monolithic but rather complex and various, and that Islam is connected with other religions.

Dalia Mogahed wishes that more Westerns would be aware that Islam doesn't motivate for violence and terrorist actions any stronger than other religions. Her position in Gallup ${ }^{6}$ enabled her to have a good survey over many researches. The researches confirm that there is no correlation between Islamic religion and sympathy for terroristic actions. According to Mogahed, if anything then stronger religiosity among Muslims contributes to propensity of refusal of terrorism among Muslims. "Islam as a net influence is the reason we don't have more hate and animosity between Muslims and the West." She believes that if more people knew these data and reflected about their implications then maybe the public view on Islam would start to change (Green 2015, 322).

The basic strategy to combat IPH is development of interpersonal contacts, relationships and common activities with non-Muslims. In this respects the mosques are very important. They must be(come) much more than just places for prayer. They must be the places of gathering where also non-Muslims can and may come, where they are welcome and can be active. Muslims must invest much more to achieve that non-Muslims will get to know them and take up with them.

6 "Mogahed is the former Executive Director of the Gallup Centre for Muslim Studies, a non-partisan research centre that provided data and analysis to reflect the views of Muslims all over the world." (https://en.wikipedia.org/wiki/Dalia_Mogahed (30.01.2016)). There "she oversaw the analysis of surveys of Muslims globally from 2006 to 2012." (Green 2015, 339) 
The civic engagement is also important. According to Mogahed, Muslims shouldn't be only guests on the West, because guests don't build, but rather engaged citizens who build (together with non-Muslims) and also sacrifice themselves for the common goals and good of society. IPH pushes Muslims in isolation when exactly the opposite is what we need, that Muslims are more engaged. They must become more visible, more prominent, and this not only in cases when they talk about Islam. As Tariq Ramadan stressed, the term integration is not appropriate for the present Muslims condition in Europe. We must leave it behind. Now it is time for contribution, for Muslims becoming an additional value of the West. Patel's message for the American Muslims is the same: Muslims must give their contribution to society and thus develop relationships and ties with other citizens. Myriam Francois-Cerrah encourages Muslims to abandon the us-versus-them narrative (Green 2015, 324-325).

It is very important that non-Muslims loudly and clearly publicly point to IPH and interrupt it. Often we can do this easier then Muslims themselves. Mogahed has pointed out that IPH will last if those who are not its direct victims remain silent. No prejudice in history has ever been overcome without a broader critical mass in the society which opposed it. Therefore we need broader coalitions also to overcome IPH. Patel warns us that we must be careful not to accuse of IPH everyone who has prejudices toward Muslims. This warning gets special weight if we take into account that sometimes it is more productive to "seduce" somebody with "beauty" than to criticise and accuse him of IPH. Patel said that we should sing to those who have prejudices against Muslims a beautiful Muslim song that they would like. Nobody changes by being scolded but rather by being introduced to beauty. This idea fits very well with the call to Muslims to cultivate interreligious dialog and interpersonal engagement, actions and projects together with non-Muslims. Myriam Francois-Cerrah agrees that relations of Muslims with people of other faith are important, but at the same time she points out that stressing too much the agreement between religions is dangerously close to the relativism, and that it encourages the understanding that it is only superficial. Combating IPH doesn't mean to make pressure on Muslims and non-Muslims to agree, but rather to accept the legitimate differences between religions, and to learn to live with differences. Ramadan encourages non-Muslims to set "difficult" questions to Muslims: about violence, terrorism, condition of women... Muslims should be asked about their views on 
these questions. By this, according to Ramadan, we show that we care for Muslims and for victims among them, but that at the same time we are not prepared - because of this - to accept everything. By this Ramadan already gives the answer to the question whether our struggle against IPH hinders our opposing towards radical Islamism and terrorism (Green 2015, 327-330).

\section{CONCLUSION: THE IMPORTANCE OF THE COMMUNITY OF CIVILIZED PEOPLE}

Armstrong (2009, 19-20) pointed out the important distinction: to be a good member of this or that civilization doesn't mean yet to be civilized. He illustrates this point by citing Mahatma Gandhi's words. When Gandhi was asked about his opinion about the Western civilization he answered: "It would be a very good thing." (Armstrong 2009, 19) Gandhi didn't want to say that he didn't appraise the achievements of Plato, Michelangelo, Mozart, Goethe, Einstein et al., that he didn't respect Jesus, Bible etc., but rather that not enough people live according to the spirit of the best achievements and persons of the West. Armstrong distinguishes between "distinctive commonalities" of each civilization and its "rich accomplishments." The first are specific characteristics and elements of particular civilization which make up their way of life. The second are its highest achievements (like Gospels for the West, like Qur'an for the Islamic civilization). Distinctive commonalities are those which separate different civilizations, while reach accomplishments connect - as the allies - all otherwise different civilizations against barbarism. The sketches of civilizations, as organic unities with shared meanings and way of life, depend on sufficient extent of the mentioned two elements. This extent is a quantitative segment of civilization. But it is not sufficient for civilization (in a proper sense). The second, qualitative constituent is needed. Real civilization depends on the endorsing and cultivation of what is the best in its tradition:

Civilization depends upon how good the widespread conception of life is; or, to put it another way, how widespread the good conception is. (Armstrong 2009, 20)

But unfortunately there is often disharmony between the widespread common culture of certain civilization and the spirit of its reach accomplishments: 
There is often a painful split: it seems as though loyalty becomes common and widespread only when it betrays the rich accomplishments to which it pays lip service, while the real nature of these accomplishments is appreciated by a relatively small number of people. (Armstrong 2009, 20)

Dialogue and peaceful coexistence demand not only people who belong to civilizations, but also that these people are civilized; they depend on the community of civilized people which is big and widespread enough. The members of this community are virtuous people. They are more "subtle and refined," they "distinguish more carefully between degrees of importance," they "leave behind the official loyalty" of their "society which function in a more coarse and unambitious way." Such a community is real despite its greater elusiveness (Armstrong 2009, 20). To create such civilized community is the central and common task of all people of good will, Muslims and non-Muslims. Its fulfilling is incompatible with radical Islamism and $\mathrm{IPH}$, and at the same time a fundamental integral part of their overcoming.

To conclude: Radical Islamism and IPH are two extremes that are very dangerous and hard to combat. Yet, this is not impossible and there are, despite difficult present situation, ways to overcome them and some reasons for optimism that we will be - at the end - successful in these efforts. This can be accomplished only if both sides fulfil their tasks, and of course in the way of dialogue and united efforts of us both, Muslims and non-Muslims. It is obvious that such an unspoiled relationship and cooperation are possible only on the basis of respecting of human dignity of every person, (social) justice, mutual respect, solidarity, and striving for the common good.

\section{ACKNOWLEDGMENT}

This paper is a result of the The Research Programme Ethical-religious Grounds and Perspectives of the Society and the Religious Studies in Context of Education and Violence (P6-0269) and basic research projects The Return of the Religious in Postmodern Thought as a Challenge for Theology (J6-7325), Reanimating Cosmic Justice: Poetics of the Feminine (J6-8265) and Interreligious Dialogue - a Basis for Coexisting Diversity in the Light of Migration and the Refugee Crisis (J6-9393), which are financed by the Slovenian Research Agency. 


\section{REFERENCES}

Armstrong J. (2009), In Search of Civilization: Remaking a Tarnished Idea, London. Buber M. (1982), Das Problem des Menschen, Heidelberg.

Cliteur P., Gordon G. (2009), The Enlightenment in Contemporary Cultural Debate, in: B. C. Labuschagne, R. W. Sonnenschmidt, Religion, Politics and Law: Philosophical Reflections on the Sources of Normative Order in Society. Leiden and Boston, pp. 311-331.

Fallaci O. (2004), Bes in ponos (Slovenian trans. of the Italian original La rabbia e l’orgoglio), Tržič.

Green T. H. (2015), The Fear of Islam. An Introduction to Islamophobia in the West, Minneapolis.

Hirsi Ali A. (2010), Nomad: From Islam to America: A Personal Journey through the Clash of Civilizations, New York.

Huntington S. P. (1993), The Clash of Civilizations?, "Foreign Affairs" 72, pp. 22-49.

Huntington S. P. (1996), The Clash of Civilizations and the Remaking of the World Order, New York.

Commission on British Muslims and Islamophobia (1997), Islamophobia: A Challenge for Us All, London, Freely accessible at: http://www.runnymedetrust.org/publications/17/32.html (30.01.2016).

Israel J. I. (2001), Radical Enlightenment. Philosophy and the Making of Modernity 16501750 , Oxford.

Israel J. I. (2006), Enlightenment Contested. Philosophy, Modernity, and the Emancipation of Man 1670-1752, Oxford.

Lean N. (2012), The Islamophobic Industry: How the Right Manufactures Fear of Muslims, London.

Lewis B. (1990), The Roots of Muslim Rage, "Atlantic" (September), pp. 47-6o.

Safaverdi S. (2008), 27 Hours in J. F. Kennedy Airport, Teheran etc.

Said E. W. (2003), The Clash of Definitions, in: The New Crusades: Constructing the Muslim Enemy, eds. E. Qureshi, M. Sells, New York, pp. 68-87.

Wajahat A. et al. (2011), Fear, Inc.: The Roots of Islamophobia Network in America, Washington.

Žižek S. (2015), On The Refugee Crisis, Islam and Multiculturalism. Part of the Žižek's lecture in Deutsches Haus at NYU and the Department of German at NYU titled Is Hegel Dead-Or Are We Dead in the Eyes of Hegel? A Hegelian View of the Present Age, freely accessible at: https://www.youtube.com/watch?v=LVa4ERqz97o (30.01.2016). 
